\title{
The importance of Leptospira interrogans serovars Icterohaemorrhagiae and Canicola in coastal zone and in southern fields of Rio Grande do Sul, Brazil ${ }^{1}$
}

\author{
Felipe J. Silva ${ }^{2 *}$, Carlos E.P. Santos ${ }^{3}$, Glaucenyra C.P. Silva², Renata F. Santos ${ }^{2}$, \\ Vera C.M. Curci ${ }^{4}$ and Luis A. Mathias ${ }^{2}$
}

\begin{abstract}
Silva F.J., Santos C.E.P., Silva G.C.P., Santos R.F., Curci V.C.M. \& Mathias L.A. 2014. The importance of Leptospira interrogans serovars Icterohaemorrhagiae and Canicola in coastal zone and in southern fields of Rio Grande do Sul, Brazil. Pesquisa Veterinária Brasileira 34(1):34-38. Departamento de Medicina Veterinária Preventiva e Reprodução Animal, Faculdade de Ciências Agrárias e Veterinárias de Jaboticabal, Universidade Estadual Paulista, Via de Acesso Professor Paulo Donato Castellane s/n, Jaboticabal, SP 14884-900, Brazil.E-mail: fjsepi@gmail.com

This study aimed to describe the occurrence of Leptospira interrogans serovars Icterohaemorrhagiae and Canicola, in coastal zone and in southern grasslands of Rio Grande do Sul, Brazil. In each one of the four analyzed farms blood samples were collected from free-living wild animals, domestic animals and humans to perform serological testing for leptospirosis. The presence of antibodies was verified by microscopic agglutination test (MAT). The criterion adopted to consider a serum as agglutination reactant was at least $50 \%$ of leptospira for a microscopic field of 100x. From 17 blood samples collected at Chuí, five (29.41\%) were positive, three $(60.00 \%)$ for serovar Icterohaemorrhagiae and two $(40.00 \%)$ for Canicola. From 21 samples collected in the County of Santana da Boa Vista, six (28.57\%) were positive, four $(66.67 \%)$ for serovar Canicola and two $(33.33 \%)$ for serovar Icterohaemorrhagiae. From 32 samples collected at Alegrete, 10 (31.25\%) were positive, seven $(70.00 \%)$ for serovar Icterohaemorrhagiae and three (30.00\%) foro serovar Canicola. From 17 blood samples collected in Cruz Alta, three (17.64\%) were positive, two (66.67\%) for serovar Icterohaemorrhagiae and one (33.33\%) for Canicola. It is necessary to improve sanitary practices on farms in the state of Rio Grande do Sul, in order to achieve success in leptospirosis control programs.
\end{abstract}

INDEX TERMS: Leptospirosis, Leptospira interrogans, farms, Rio Grande do Sul.

RESUMO.- [A importância de Leptospira interrogans sorovariedades Icterohaemorrhagiae e Canicola na zona litorânea e nos campos sulinos do Rio Grande do Sul.] 0

\footnotetext{
${ }^{1}$ Received on October 28, 20p13.

Accepted for publication on November 22, 2013.

${ }^{2}$ Departamento de Medicina Veterinária Preventiva e Reprodução Animal, Faculdade de Ciências Agrárias e Veterinárias de Jaboticabal (FCAV), Universidade Estadual Paulista (Unesp), Via de Acesso Professor Paulo Donato Castellane s/n, Jaboticabal, SP 14884-900, Brazil. E-mails: glaucenyracecilia@gmail.com,renatafdsantos@hotmail.com,lmathias@ fcav.unesp.br; *Corresponding author: fjsepi@gmail.com

${ }^{3}$ Departamento de Clínica Médica Veterinária, Faculdade de Agronomia, Medicina Veterinária e Zootecnia, Universidade Federal de Mato Grosso (UFMT), Av. Fernando Correa da Costa 2367, Cuiabá, MT 78068-900, Brasil. E-mail: carloseduardo@ufmt.br

${ }^{4}$ Unidade de Pesquisa e Desenvolvimento de Araçatuba/APTA/Secretaria de Agricultura, Av. Alcides Fagundes Chagas 122, Araçatuba, SP 16055565, Brazil. E-mail: vlmcurci@apta.sp.gov.br
}

presente estudo teve como objetivo descrever a ocorrência de Leptospira interrogans sorovariedades Icterohaemorrhagiae e Canicola, na zona litorânea e nos campos sulinos do Estado do Rio Grande do Sul. Em cada uma das quatro propriedades foram realizadas colheitas de sangue de animais selvagens de vida livre, de animais domésticos e de seres humanos para realização de sorologia para leptospirose. A presença de anticorpos foi verificada pela técnica de Soroaglutinação Microscópica (SAM). 0 critério adotado para considerar um soro como reagente foi aglutinação de pelo menos 50\% das leptospiras no campo microscópico no aumento de 100x. Das 17 amostras de sangue colhidas na propriedade pertencente ao Município de Chuí, cinco $(29,41 \%)$ foram positivas, três $(60,00 \%)$ à sorovariedade Icterohaemorrhagiae e duas $(40,00 \%)$ à Canicola. Das 21 amostras colhidas em Santana da Boa Vista, seis $(28,57 \%)$ foram positivas, quatro 
$(66,67 \%)$ à Canicola e duas $(33,33 \%)$ à Icterohaemorrhagiae. Das 32 amostras colhidas em Alegrete, 10 (31,25\%) foram positivas, sete $(70,00 \%)$ à Icterohaemorrhagiae e três $(30,00 \%)$ à Canicola. Das 17 amostras colhidas em Cruz Alta, três $(17,64 \%)$ foram positivas, duas $(66,67 \%)$ à Icterohaemorrhagiae e uma $(33,33 \%)$ à Canicola. É necessário melhorias nas práticas sanitárias em propriedades rurais do Estado do Rio Grande do Sul, a fim de se obter sucesso em programas locais de controle da leptospirose.

TERMOS DE INDEXAÇÃO: Leptospirose, Leptospira interrogans, propriedades rurais, Estado do Rio Grande do Sul.

\section{INTRODUCTION}

Although leptospirosis is known as an occupational disease in most countries, in Brazil it is acquired through contact with water contaminated by infected animals urine, being your epidemiological characteristic associated with socioeconomic conditions (Romero et al. 2003). In addition to this description, epidemiological characteristics and risk factors for leptospirosis in rural areas are different from those of urban areas, being that, at the first, the transmission occurs more frequently because of deficiency of good sanitary practices in handling animals.

In a research about leptospirosis epidemiology, Virginie, Branger \& Genevieve (2002) described the zoonosis importance to public health, presenting a lethality of $10 \%$ in Brazil, and reported the isolation of the serovar Icterohaemorrhagiae in Myocastor coypus, Rattus norvegicus and Rattus ratus.

Howerth et al. (1994), in a research about diseases in Myocastor coypus in Louisiana, they found $7 \%$ of seropositive animals to Leptospira spp., all of them to serovar Canicola.

The present study aimed to describe the occurrence of Leptospira interrogans serovars Icterohaemorrhagiae and Canicola in rural farms from coastal zone and southern grasslands of Rio Grande do Sul State, Brazil.

\section{MATERIALS AND METHODS}

The present study is part of a doctoral research at Departamento de Medicina Veterinária Preventiva e Reprodução Animal, Faculdade de Ciências Agrárias e Veterinárias de Jaboticabal, Universidade Estadual Paulista (FCAV-Unesp), in which the aim was to describe the epidemiological situation of leptospirosis in small rural properties in different Brazilian Biomes. Therefore, the counties were selected taking into account the weather conditions, relief, hydrography and natural vegetation of each site as well as their socioeconomic characteristics.

The properties, in which the field activities were realized, belong to the counties of Chuí, Santana da Boa Vista, Alegrete and Cruz Alta, being the first belonging to the biome Coastal Zone, and the others to Southern Grasslands, all of them in Rio Grande do Sul State. There was analyzed one property in each one of the four counties of the state. The figure 1 shows the Rio Grande do Sul State map with the exact coordinates of each property.

In each one of the four properties blood samples were collected from free-living wild animals, domestic animals and humans to perform serological test for leptospirosis.

Via cephalic or basilica venipuncture, using sterile disposable needles and syringes, blood samples were collected from humans. The whole procedure was performed by a properly trained nurse and each volunteer was agreed and signed the "Term of Consent",

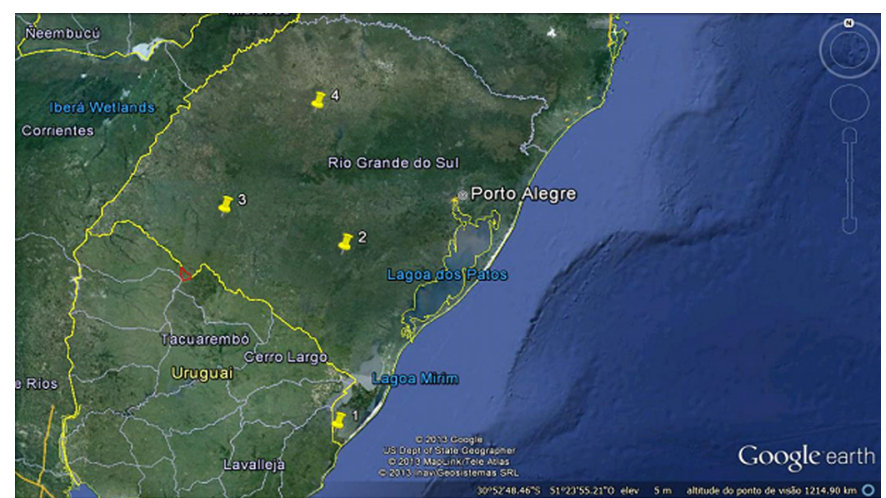

Fig.1. Map of Rio Grande do Sul, Brazil, with the exact coordinates of each rural property studied (Google Earth, 2013); (1) Rural property of the County Chuí (33o34'12.25"S 53o30'49.19”0). (2) Rural property of the County Santana da Boa Vista (30047'49.35"S 53013'20.10"0). (3) Rural property of the County Alegrete (30o10'52.81"S55012'42.54"0). (4) Rural property of the County Cruz Alta (28037'19.92"S 53o33'14.07”0).

referring to the authorization of the Comitê de Ética em Pesquisa HCRP 14630/2010. Before and immediately after each blood sampling was performed the disinfection of the site with povidone iodine or iodine alcohol.

All the capture procedure, physical and/or chemical restraint and material harvesting of wild free-living and domestic animals were made by the most appropriate manner, respecting the particularities of each species. Animals of both sexes and all age groups were analyzed. Collections of blood samples were made through jugular, caudal or cephalic vein puncture, depending on the specie, using sterile disposable needles and syringes. Before and immediately after each blood sampling there was performed the disinfection of the site with povidone iodine or iodine alcohol. For this paper, authorization was granted by the Instituto Brasileiro do Meio Ambiente e dos Recursos Naturais Renováveis (IBAMA), grant number 26185-1 (issue date: 2 July 2011 at 16:18 h) and authorization of the Comissão de Ética no Uso de Animais (CEUA), protocol number 027 958/10 (date of issue: 20 December 2010), document that still puts the present research work is in accordance with the Princípios Éticos na Experimentação Animal, adopted by Colégio Brasileiro de Experimentação Animal (COBEA).

Blood samples freshly harvested were transferred to tubes type vaccutainer and kept at room temperature until coagulation and clot retraction, and subsequently transported under refrigeration until an installed base in each property. The samples were centrifuged at $1.000 \mathrm{G}$ for 15 minutes. The serum aliquots were transferred to $2.0 \mathrm{~mL}$ polypropylene plastic tubes and kept under freezing temperature, $-20^{\circ} \mathrm{C}$, until the time of the examinations in FCAV-Unesp.

The presence of antibodies was verified by the microscopic agglutination test (MAT), from 1/50 dilution, being one part of blood serum to 49 parts of $0,85 \%$ saline solution. From this dilution were put $25 \mathrm{uL}$ aliquots in polyethylene plates with flat bottom, and the same amount of antigen were put together, resulting in 1/100 dilution. The plates were incubated in bacteriological incubator at $28^{\circ} \mathrm{C}$ during one hour. The lection was done in darkfield microscopy directly from the plate, using 10x rise object-glass and a 10x rise ocular (Santa Rosa et al. 1975, Santa Rosa et al. 1980).

The criterion adopted to consider a serum as reactant was the agglutination of at least $50 \%$ of leptospiras in the microscopic field in the 100x rise (Santa Rosa et al. 1975, 1980).

The Leptospira spp serovars used were Icterohaemorrhagiae, Copenhageni, Grippotyphosa, Pomona, Canicola, Hardjo, Wolffi, 
Tarassovi, Hebdomadis, Panama, Pyrogenes, Shermani, Patoc, Castellonis, Bataviae, Autumnalis, Andamana, Australis, Sentot, Javanica, Bratislava, Whiticombi, Cynopteri, Butembo.

The Leptospira spp. serovars used as antigens came from matrices which were weekly subcultured in liquid culture medium EMJH (Ellighausen, McCullough, Johnson e Harris - Difco ${ }^{\mathrm{R}}$ ) with $10 \%$ of the volume of the medium to seed and kept in an bacteriological incubator $\mathrm{BOD}$ at $28^{\circ} \mathrm{C}$. All the antigens were pure and were used around the sixth incubation day. The concentration considered optimal was standardized to correspond to half turbidity of the tube number 1 in MacFarland scale (about 100 to 200 leptospires per microscopic field), according to the Sulzer \& Jones (1980) technique. The cultures were free from contamination and autoagglutination.

\section{RESULTS}

In the rural property at Chuí, blood samples were collected from three people, one dog, one horse, six sheep, two Cerdocyon thous, one Myocastor coypus and three Dasypus septemcinctus. In the rural property at Santana da Boa Vista, blood samples were collected from three people, four dogs, two horses, six sheep and six Dasypus septemcinctus. In the rural property at Alegrete, blood samples were collected from two people, five dogs, six horses, 13 sheep, one Leopardus tigrinus, one Cerdocyon thous and four Dasypus septemcinctus. In the rural property at Cruz Alta, blood samples were collected from two people, two dogs, one horse, nine sheep and three Dasypus septemcinctus.

Figure 2 shows the number of free-living wild animals,

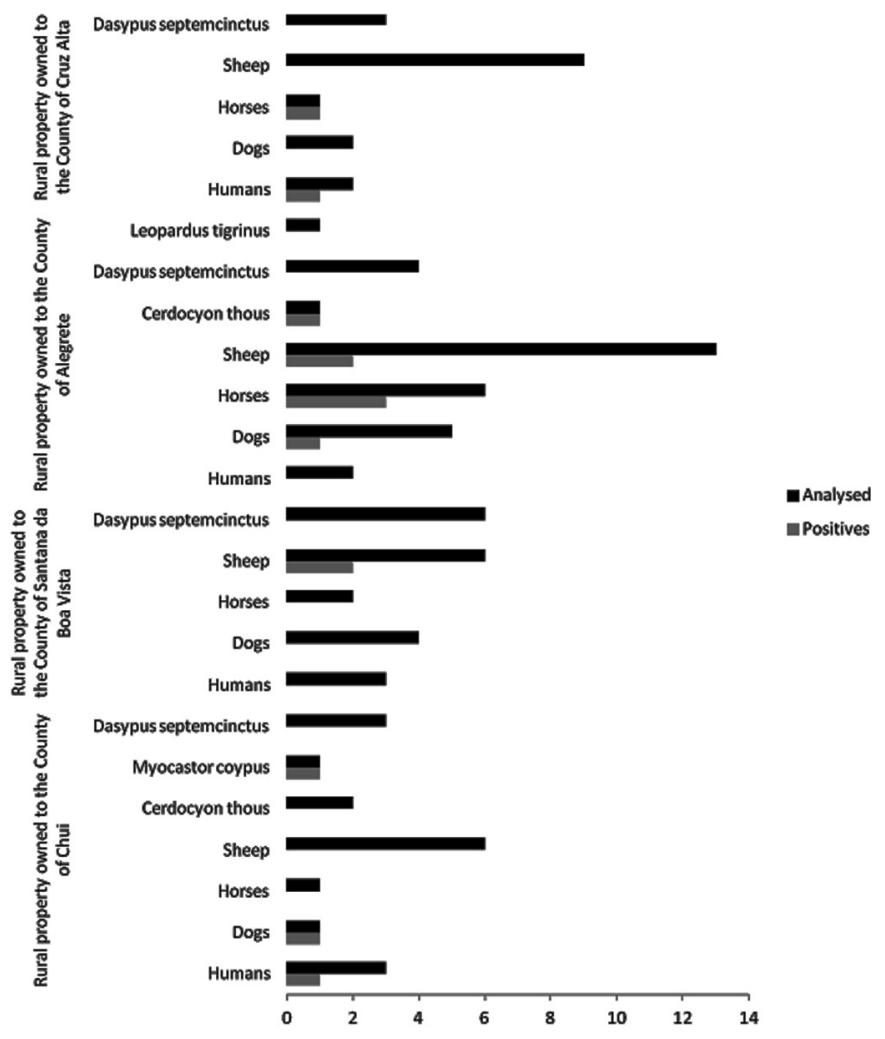

Fig.2. Free-living wild animals, domestic animals and human reactants to Leptospira interrogans serovar Icterohaemorrhagiae among analyzed in each of the four farms belonging to the respective counties of the State of Rio Grande do Sul. 2013. domestic animals and human reactants to Leptospira interrogans serovar Icterohaemorrhagiae among the analyzed and Figure 3 shows the number of free-living wild animals, domestic animals and human reactants to Leptospira interrogans serovar Canicola among the analyzed in each of the four farms belonging to the respective counties of Rio Grande do Sul State.

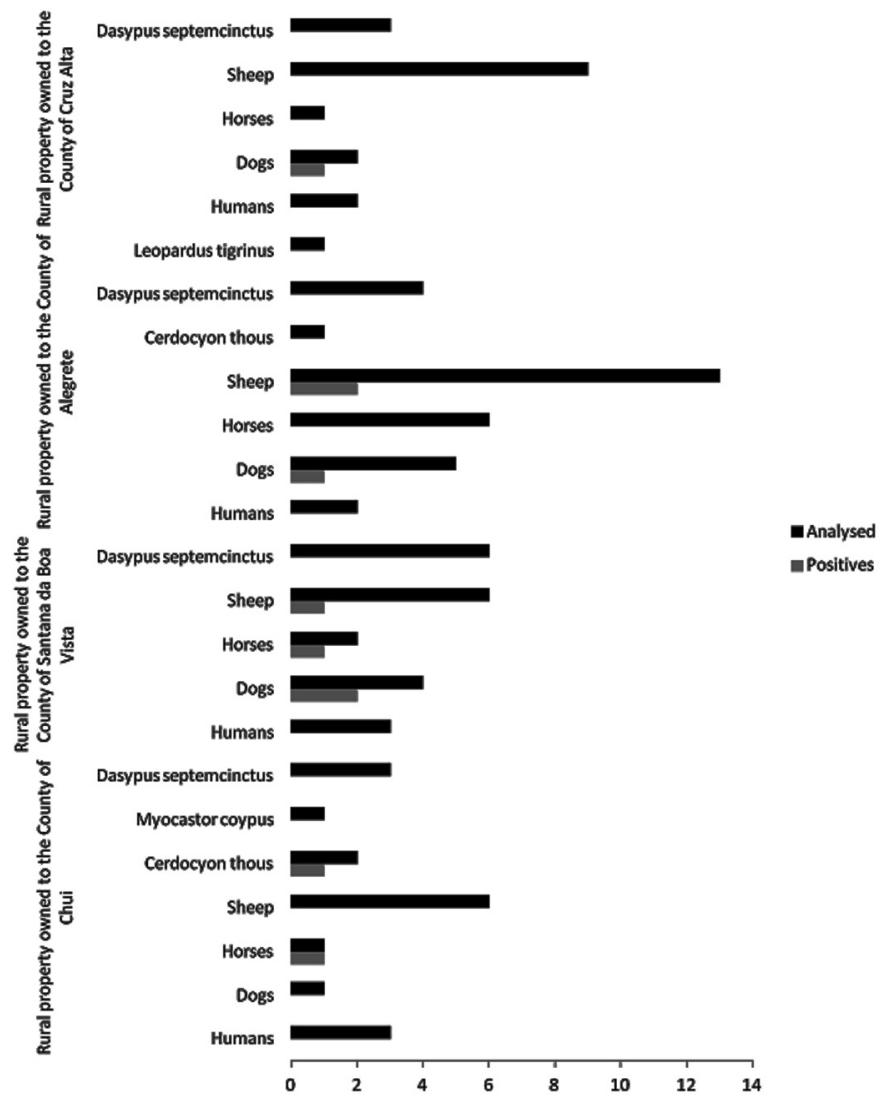

Fig.3. Free-living wild animals, domestic animals and human reactants to Leptospira interrogans serovar Canicola among analyzed in each of the four farms belonging to the respective counties of the State of Rio Grande do Sul. 2013.

From 17 blood samples collected at Chuí, five (29.41\%) were positive, three (17.64\%) to serovar Icterohaemorrhagiae and two $(11.76 \%)$ to Canicola. From the three humans analyzed, one $(33.33 \%)$ was positive, being reactant to serovar Icterohaemorrhagiae. The only dog analyzed was reactant to serovar Icterohaemorrhagiae and the only horse analyzed was reactant to serovar Canicola. None of the six sheep analyzed at Chuí was positive. Of the two Cerdocyon thous analyzed, one (50.00\%) was positive, being reactant to serovar Canicola and the only Myocastor coypus analyzed was reactant to serovar Icterohaemorrhagiae. None of the three Dasypus septemcinctus analyzed was positive.

From 21 samples collected in the County of Santana da Boa Vista, six (28.57\%) were positive, four (19.04\%) to serovar Canicola and two $(9.52 \%)$ to serovar Icterohaemorrhagiae. None of the three human was positive. From the four dogs analyzed, two (50.00\%) were positive, both to serovar Canicola. Of the two horses analyzed, one 
(50.00\%) was positive, being reactant to serovar Canicola. From the six sheep analyzed, three $(50.00 \%)$ were positive, two $(33.33 \%)$ to serovar Icterohaemorrhagiae and one $(16.67 \%)$ to Canicola. All of the six wild animals analyzed at Santana da Boa Vista were negative by MAT.

From 32 samples collected at Alegrete, ten (31.25\%) were positive, seven $(21.87 \%)$ to serovar Icterohaemorrhagiae and three $(9.37 \%)$ to serovar Canicola. None human analyzed was positive. From the five dogs examined, two $(40.00 \%)$ were positive, one $(20.00 \%)$ to serovar Icterohaemorrhagiae and one $(20.00 \%)$ to Canicola. From the six horses analyzed, three (50.00\%) were positive, all reactant to serovar Icterohaemorrhagiae. From the 13 sheep analyzed, four (30.77\%) were positive, two (15.38\%) to serovar Icterohaemorrhagiae and two (15.38\%) to Canicola. The only Cerdocyon thous analyzed was reactant to serovar Icterohaemorrhagiae. Neither Dasypus septemcinctus nor the Leopardus tigrinus were positive.

From 17 blood samples collected in Cruz Alta, three (17.64\%) were positive, two (11.76\%) to serovar Icterohaemorrhagiae and one $(5.88 \%)$ to Canicola. From the two humans analyzed, one (50.00\%) was positive, being reactant to serovar Icterohaemorrhagiae. Of the two dogs examined, one $(50.00 \%)$ was positive, being reactant to serovar Canicola. The only horse analyzed was reactant to serovar Icterohaemorrhagiae and none of the nine sheep analyzed was positive. All Dasypus septemcinctus analyzed in Cruz Alta were negative.

\section{DISCUSSION}

The results found in Chuí reinforce the possible transmission of this etiologic agent between wildlife, domestic animals and humans and is a warning to the possible condition of the species Myocastor coypus, rodent with aquatic habitat, as a reservoir of Leptospira interrogans. Further emphasizing the importance of these findings, the property studied in the County of Chuí has most of its areas flooded by the plated condition that favors the transmission of leptospirosis among species, showing a framework of relevance for animal, public and environmental health, especially when it comes to the serovar Icterohaemorrhagiae, which rodents are reservoirs and is quite pathogenic for humans. Howerth et al. (1994), in a survey of disease in Myocastor coypus Louisiana, found $7 \%$ of seropositive animals, all to the serovar Canicola. In a survey about the leptospirosis epidemiology, Virginie et al. (2002) described the importance of this zoonosis to public health, showing a fatality rate of $10 \%$ in Brazil, and reported the isolation of serovar Icterohaemorrhagiae in Myocastor coypus, Rattus norvegicus and Rattus ratus.

The results obtained in Santana da Boa Vista focus on the importance of serovar Canicola for animal health and emphasize the importance of the contact of domestic animals with rodents in the transmission of serovar Icterohaemorrhagiae.

The findings in Alegrete place the role of free-living wild animals as reservoirs of serovar Icterohaemorrhagiae to domestic animals. Furthermore, there is a growing presence of serovar Canicola in production domestic animals such as small ruminants, and work such as horses.
The results found in Cruz Alta demonstrate the importance of serovar Icterohaemorrhagiae for both public and animal health, also representing an important indicator of environmental health because of the wide diversity of wild animals acting as reservoirs for this serovar. The presence of serovar Canicola in one of the dogs examined reinforce the role of the Canidae Order in the predilection of this serovar.

Although leptospirosis is known as an occupational disease in most countries, in Brazil it is acquired through contact with contaminated water containing urine from infected animals, being your epidemiological characteristic associated with socioeconomic conditions (Romero, Bernardo \& Yasuda 2003). In addition, you can put that the epidemiological characteristics and the risk factors for leptospirosis in rural areas are different from those of urban areas, and, in the first, the transmission occurs more frequently because of deficiency in good sanitary practices in animals handling.

The poor sanitary practices, too observed in rural properties in Rio Grande do Sul State, such as accumulation of rubbish and organic waste, lack of hygiene on animals feeders and drinkers, poor storage of the food and negligence with water quality, promote the proliferation of synanthropic organisms (rats, cavies) and free-living wild animals (Cerdocyon thous, Dasypus septemcinctus, Leopardus tigrinus, Myocastor coypus) around the properties and thus narrows the contact between these potential reservoirs, people and their domestic animals. It is well known that the transmission of this agent is more facilitated during the rainy season, even in rural areas, but close contact with wildlife reservoirs occur all year long, which makes the environment of a rural property (pastures, picket, stalls, feeders, milking parlor, feed sheds, drinkers) be constantly exposed to this etiologic agent through the urine of infected animals.

\section{CONCLUSIONS}

The serovars of Leptospira interrogans Icterohaemorrhagiae and Canicola are present in free-living wild animals, domestic animals and humans on farms in Rio Grande do Sul State, especially by environmental conditions provided by the plains and swamps of the southern grassland and the bad hygiene habits commonly observed properties of this state.

The serovar Icterohaemorrhagiae has rodents as reservoir, and the specie Myocastor coypus deserves attention in future studies as an important transmitter of this bacteria for humans and domestic animals, especially by being a specie with aquatic habitat, condition which favors the transmission of the etiological agent of this zoonosis.

The serovar Canicola is present in wild and domestic dogs and deserves attention in relation to its increasing importance to animal health.

As performed in the study from which this paper derives, Leptospira spp isolation studies are needed to indeed investigate the transmission of this etiologic agent among free-living wild animals, domestic animals and humans in farms and, from that, to put in place specific measures to control leptospirosis. 
Hard work is need for improvements in health practices on farms of Rio Grande do Sul State, in order to succeed in programs for local control of leptospirosis and other zoonotic diseases.

Acknowledgements.- To Universidade Estadual Paulista, Campus de Jaboticabal, FCAV-Unesp, and to Fundação de Amparo à Pesquisa do Estado de São Paulo (FAPESP).

\section{REFERENCES}

Howerth E.W., Reeves A.J., McElveen M.R. \& Austin F.W. 1994. Survey for selected diseases in nutria (Myocastor coypus) from Louisiana. J. Wildl. Dis. 30:450-453.
Romero E.C., Bernardo C.C.M. \& Yasuda P.H. 2003. Human leptospirosis: a twenty-nine-year serological study in São Paulo, Brazil. Revta Inst. Med. Tropical São Paulo 45(5):245-248.

Santa Rosa C.A., Sulzer C.R., Giorgi W., Silva A.S., Yanaguita R.M. \& Lobão A.0. 1975. Leptospirosis in wildlife in Brazil: isolation of a new serotype in pyrogenes group. Am. J. Vet. Res. 36:1363-1365.

Santa Rosa C.A., Sulzer C.R., Yanaguita R.M. \& Silva A.S. da. 1980. Leptospirosis in wildlife in Brazil: isolation of serovars Canicola, Pyrogenes and Grippotyphosa. Int. J. Zoonosis 7:40-43.

Sulzer C.R. \& Jones W.L. 1980 Leptospirosis: method in laboratory diagnosis. Center for Diseases Control, Atlanta.

Virginie M., Branger C. \& Genevieve A.F. 2002. Epidemiology of Leptospirosis. Revta Cubana Med. Tropical 54(1):7-10. 